Кулаков Руслан

кандидат психологічних наук, доцент кафедри вікової та педагогічної психології Рівненського державного гуманітарного університету http://orcid.org/0000-0003-0033-8784 DOI https://doi.org/10.35619/praprv.v1i15.189

\title{
РОЗВИТОК ЕМПАТІЇ У ДІТЕЙ МОЛОДШОГО ШКІЛЬНОГО ВІКУ В УМОВАХ ОСВІТНЬОГО ПРОЦЕСУ
}

Анотація. Стаття присвячена актуальній проблемі сучасної психолого-педагогічної науки - розвитку емпатії у дітей молодшого шкільного віку. У публікації обтрунтовано наукову й практичну значущість проблеми розвитку емпатії у дітей молодшого шкільного віку. У статті розглядаються підходи до визначення поняття «емпатія» у психологічній науці, наводяться певні точки зору вчених на природу та онтогенетичні особливості виникнення цього соціально-психологічного явища. Визначено основні види, форми прояву емпатії, з'ясовано ї̈ основні функиї. Здійснено аналіз основних рівнів розвитку емпатії. Розглядаються основні закономірності розвитку емпатії у молодших школярів в умовах навчальної діяльності у школі. 3'ясовано роль педагогів в успішному розвитку емпатійності дитини молодшого шкільного віку. У публікації проаналізовано основні етапи, методи, форми та напрями психолого-педагогічного супроводу розвитку емпатії в учнів початкових класів.

Ключові слова: емпатія, емпатійні здібності, емочійна сфера, молодиий шкільний вік, молодші школярі, навчальна діяльність, освітній процес.

Постановка проблеми. Актуалізація нових цінностей в освіті, кардинальні зміни у соціально-культурному житті суспільства вимагають виховання людей нового типу. Згідно «Державного стандарту початкової освіти», одним із ціннісних орієнтирів початкової освіти $\epsilon$ «утвердження людської гідності шляхом виховання чесності, відваги, наполегливості, доброти, здатності до співчуття і співпереживання, справедливості, поваги до прав людини...» (2019). 3 цим положенням важко не погодитись, адже розвиток особистості, здатної до співчуття, співпереживання, сприйняття емоційних проявів іншої людини забезпечує іiі успішну адаптацію у сучасному соціокультурному просторі. Одне із найважчих завдань виховання - навчити дитину «бачити та відчувати людей». Розвиток емпатії $\epsilon$ невід'ємною частиною формування особистості, виховання у індивіда культури міжособистісної взаємодії, розвитку здатності дитини керувати своїми почуттями та переживаннями. Саме емпатія є основою розвитку емоційно-почуттєвої сфери, здатності розуміти та керувати своїми почуттями, переживаннями, а також уміння і бажання зрозуміти емоції, почуття, настрій іншою людини. Сухомлинський (1983) зазначав, що глухий до людей залишиться глухим до себе, оскільки залишиться недоступною найголовніша складова процесу самовиховання - емоційна оцінка власних вчинків.

У психолого-пдагогічній літературі період шкільного навчання відзначається як етап інтенсивного соціального, психологічного та особистісного розвитку дитини. Велика кількість психологів визначають молодший шкільний вік як найбільш сензитивний період для розвитку емоційно-моральної сфери, зокрема і емпатичних здібностей. Адже у цьому віці у дітей починають формуватися моральні цінності, нові погляди на стосунки між людьми. Варто зазначити, що усе засвоєне та пережите у цьому віковому періоді характеризується психологічною стійкістю. Тому недоліки особистісного розвитку та виховання важко буде компенсувати у наступні вікові періоди. Молодший шкільний вік $\epsilon$ найбільш відповідальним етапом у розвитку соціальних механізмів поведінки дитини. Молодші школярі проявляють активне прагнення до спілкування із ровесниками у різних видах діяльності, проявляють свою активність у навчанні, що створює підгрунтя для 
виховання колективних взаємовідносин, що базуються на механізмах співчуття, співпереживання, співдіяльності. Особливістю дитини цього віку $є$ спрямованість ії діяльності на світ соціальних відносин, у яких вона починає виокремлювати і усвідомлювати себе у системі взаємовідносин між людьми через свої досягнення у тій чи іншій діяльності, та співпереживати досягненням інших.

Аналіз останніх досліджень 3 проблеми. Величезна кількість вчених присвятили свої праці вивченню проблеми емпатії, зокрема, Тітченер, Ліппс, Ріццолатті, Барон-Коен і Вілрайт, Косоногов.

Різні аспекти розвитку особистості висвітлювалися в роботах відомих вітчизняних психологів та педагогів (Абульханова-Славська, Боришевський, Ельконін, О.В.Запорожець, Костюк, Максименко, Непомняща, Сухомлинський, та інші), які стали методологічним та теоретичним підгрунтям багатьох досліджень цієї проблеми. Серед них значне місце посідають дослідження емоційного розвитку, чутливості, сприяння та співпереживання (Джрназян, Кошелєва, Неверович, Стрєлкова). Низка досліджень була присвячена саме окремим аспектам розвитку емпатії та іiі компонентів (Алексєєва, Борисенко, Виговська, Гаврилова, Стрєлкова, Юсупов), співвідношенню емпатії та моральності (Валантінас, Соломатіна, Шевченко), впливу різних факторів на процес виховання емпатії (Агавелян, Михайліченко), сутності ематії як різновиду просоціальних тенденцій (Павелків, Корчакова).

Мета статті: вивчити й теоретично обгрунтувати особливості розвитку емпатії у дітей молодшого шкільного віку в умовах освітнього процесу.

Виклад основного матеріалу дослідження. Термін «емпатія» має грецьке походження і означає «ет»- спрямований в середину та «раthos»- глибоке, сильне почуття, близьке до страждання. Наукове поняття «емпатія» увійшло в психологію на початку нашого століття, однак історія вивчення цього питання розпочалася набагато раніше. Термін «емпатія» був введений психологом Тітченером для позначення внутрішньої активності, результатом якої $є$ інтуїтивне розуміння ситуації іншої людини. Науковець інтегрував філософські ідеї про симпатію та теорію вчування Кліффорда і Ліпса. У сучасній психології це поняття інтерпретується як «здатність індивіда емоційно реагувати на переживання інших людей, розуміти їх стан, відчуття і думки» (Психологічна енциклопедія, 2006, с. 121).

Гаврилова (2009) визначає такі форми прояву емпатії:

- співпереживання - це переживання почуттів іншої людини через ототожнення 3 нею.

- співчуття - це переживання почуттів партнера, що не співпадають із власними.

Вчені виділяють різні функції емпатії. 3 одного боку, вона виступає одним 3 визначальних факторів поведінки. Представники такого підходу (Ліппс, Рібо, Мак Дауголл, Аронфілд, Шафер, Лібхарт, Сидмен, Ролінг, Хоген, Харріс, Хоунг, Мехрабіан, Епштейн) говорять про наявність залежності між емпатичними здібностями особистості і її схильністю до альтруїзму. 3 іншого боку, емпатія - це специфічна емоційна форма пізнання, основним об'єктом якого є людина (Шелер, Аш, Роджерс, Бірес, Арлоу, Махоні, Маркус, Вілмер). Багатозначність трактувань породжує певні труднощі у виявленні і аналізі структурних компонентів цього феномена.

Сучасні дослідження за даною темою можна умовно розділити на кілька напрямків:

- Шопенгауер, Валлон, Гаврилова, Ліппс, Саллівен, Фресс, Шелер розглядають емпатію як емоційне явище;

- Даймонд, Маркус, Мід акцентують увагу на ідентифікації з партнером-афективної, когнітивної або на рівні соціальної поведінки;

- Майерс, Петровська, Роджерс, Стрєлкова, Юсупов доповнюють уявлення про афективно-когнітивної природі емпатії комунікативним елементом;

- Гіппенрейтер, Вєдєнєєва, Корягіна, Козлова вводять термін «конгруентна емпатія», що позначає комплексну здатність проявляти емпатію в мові або діях і гнучко перемикатися 3 афективного розуміння партнера на відповідь вираження власних емоцій, в тому числі негативних, зберігаючи загальне позитивне сприйняття ситуації. 
Визначають такі рівні емпатії:

Перший рівень - це найнижчий рівень. До нього належать люди, які зазвичай зосереджені виключно на собі. Вони взагалі не цікавляться думками та почуттями оточуючих людей. Інколи такі люди бувають переконаними у тому, що розуміють інших людей. Та їх думка є хибною. Адже через цілковиту концентрацію на собі вони не здатні це осягнути.

Другий тип зустрічається найчастіше. Люди, яким притаманний цей рівень емпатії, можуть ігнорувати думки та почуття інших людей не постійно, а періодично.

Третій рівень - найвищий. Люди з високим рівнем емпатії є великою рідкістю. Вони завжди глибоко відчувають оточуючих людей і здатні подумки відновити будь-які переживання свого партнера, розуміючи людей краще, ніж вони самі. Такі люди не нав'язують своєї думки і дають найефективніші поради. Люди з високим рівнем емпатії вважаються хорошими друзями та психологами.

Павелків, Корчакова (2013) стверджують, що «залежно від тривалості перебігу процесу виокремлюють короткотривалу і довготривалу емпатію. Короткотривала розрахована на обмежений контакт з іншими людьми, у процесі якого людина стає на позицію іншої. Довготривала емпатія має більш тривалий перебіг і вимагає тіснішого спілкування з іншою людиною» (с. 113).

Дефуа (2014) виділяє такі види емпатії:

- емоційна емпатія, заснована на механізмі проекції та копіювання моторних i афективних реакцій іншої людини.

- когнітивна емпатія базується на інтелектуальних процесах (порівняння, аналогія і т.д.).

- діяльнісна (поведінкова) емпатія проявляється як здатність людини передбачити афективні реакції іншої людини у конкретних ситуаціях.

Усі ці компоненти взаємодіють між собою.

Особливої значущості проблема формування емпатії набуває у молодшому шкільному віці. Молодший шкільний вік - це вік 6-11-річних дітей, що навчаються у 1-4-их класах початкової школи. Вікові межі та психологічні характеристики цього періоду визначаються теорією психічного розвитку.

Проведений теоретичний аналіз поняття емпатії дає нам можливість розглядати іiі відносно молодшого шкільного віку як здатність дитини емоційно реагувати на стан іншої людини. Вона передбачає уміння правильно розпізнавати емоційний стан іншої людини, проявляти співчуття, співпереживання, бажання надавати реальну допомогу. До найважливіших особистісних характеристик молодшого школяра належать довірливе підкорення авторитету, підвищений рівень сприймання та уважності. У поведінці учнів початкових класів проявляється конформізм на наслідувальність. У цьому віці створюються найсприятливіші умови для розвитку емпатії. Діти цього віку схильні до копіювання інших, вони довірливі, вразливі, схильні до наслідування.

Павелків (2004) стверджує: «Молодший школяр починає більш стримано виявляти власні емоції, особливо негативні, що пов'язано з розрізненням ситуацій, в яких можна чи не можна виявляти власні почуття, тобто довільність поведінки поступово починає позначатися на сфері почуттів. Однак, загалом для дітей характерні вразливість і чуйність» (с. 213). Власне $з$ початкової школи, як важливого життєвого етапу, починається формування умінь налагоджувати взаємодію між дітьми, які прийшли із абсолютно різних мікросоціумів, 3 різним життєвим комунікативним досвідом. Задля успішного навчання у класному колективі необхідно зводити ці протиріччя у процесі взаємодії до певного спільного знаменника. Саме у початковій школі важливо сформувати у дитини сприйняття іншого як значущого i цінного. У цей період найчастіше діти вперше зустрічаються із необхідністю тісної взаємодії у колективі задля досягнення спільного результату. Тому одним із головних напрямків освітнього процесу сучасної школи вважається соціалізація дитини, яка передбачає формування загальнолюдських, моральних і культурних цінностей. У зв’язку з цим сучасна 
психолого-педагогічна діяльність спрямована на розв'язання проблем, пов'язаних із спілкуванням, побудовою міжособистісних стосунків, самореалізацією, а також розвитком емоційно-почуттєвої сфери дитини. Ефективному вирішенню проблем сприяє сформованість емоційної сфери дитини, їі особистісний досвід у переживанні емоцій. В основі розвитку емоційної сфери особистості, здатності розпізнавати та керувати своїми почуттями, переживаннями лежить емпатія.

У молодшого школяра у цьому віці розвивається відчуття власного «Я». Крім того, у нього формується уявлення і про «Я» інших людей. При цьому дитина розуміє різницю між власним «Я» та «Я» інших людей. Дитина фіксує певні особливості особистості іншої людини, які відрізняються від іiї власних. Саме у цей віковий період варто навчити дитину враховувати інтереси та потреби оточуючих. У початковій школі у дитини з'являються нові соціальні ролі. Формуються міжособистісні стосунки з колективом класу, вчителями. Все це сприяє не лише набуттю нового життєвого досвіду, але і виникненню різноманітних переживань у дитини. Саме переживання у молодшого школяра формується під впливом конкретних впливів і власної реакції на них. Варто зазначити, що молодші школярі найбільше співпереживають тим, хто опинився у подібній до власної ситуації. Із цього можна зробити висновок, що розвиток почуття співпереживання у дитини молодшого шкільного віку багато в чому залежить від виховного впливу. Тому для розвитку особистості дитини найбільш важливим є виховання, за якого іії увага спрямована на почуття та дії іншої людини.

Задля того, щоб дитина навчилась розпізнавати переживання інших людей, їй необхідно побачити прояви власних переживань. Варто навчити дитину усвідомлювати те, що вона відчуває у даний момент. Причому, допомогти не просто відрізняти радість від смутку, а й зло від агресії. Так у дитини сформується більш чуйне ставлення як до себе, так і до оточуючих людей. Не можна не зосередити увагу на важливості педагогічного спілкування у розвитку емпатії у молодших школярів. Адже для дитини педагог є носієм соціально-моральних оцінок, еталоном для наслідування, орієнтиром у власній поведінці. Поступове засвоєння етичних і моральних норм суспільства дозволяє у майбутньому без проблем адаптуватися до культурного середовища, яке буде оточувати дитину. I, навпаки, відчуваючи нестачу спілкування із дорослими, дитина молодшого шкільного віку повною мірою не буде готовою до переживання різних життєвих ситуацій. Життєві ситуації та події, які дитині не вдалося пережити, відчути та усвідомити, не залишаться у її пам'яті, а тому втратять свою соціально-психологічну роль.

Як вважає Пономарьова (2006), змістом процесу розвитку емпатії повинні бути емпатогенні ситуації, що виникають у процесі взаємодії дитини з навколишнім середовищем. В першу чергу, це стихійні емпатогенні ситуації, які склалися в результаті спілкування 3 іншими людьми, спостереженнями за навколишньою дійсністю, переглядом мультфільмів, слуханням казок і т.д. Причому, під стихійними ситуаціями слід розуміти такі ситуації, які виникають на даний момент у присутності дорослого. Але не варто забувати i про емпатогенні ситуації, що виникають поза межами спостереження дорослих. Це спілкування 3 ровесниками, навчання, ігрова діяльність, образотворча діяльність і т.д.

Психолого-педагогічний супровід розвитку емпатії у дітей молодшого шкільного віку може проходити у кілька етапів. На початковому етапі варто застосовувати вправи для розвитку емоційної емпатії. Наприклад: «Намалюй свій настрій», «Заспівай про свої почуття», «Зіграй мелодію свого настрою», «Я - дизайнер», «Вгадай, що я відчуваю», «Напиши листа однокласнику, що хворіє» та ін. Наступний етап може передбачати вправи, які спрямовані на розвиток когнітивної емпатії. Доречними будуть такі завдання, як «Зображення», «Пантоміма» (модифікація за Петровським). Розвиток когнітивного компоненту емпатії дітей молодшого шкільного віку безпосередньо пов'язаний з розвитком таких процесів, як мовлення, мислення, уява, сприймання. Вони, у свою чергу, розвиваються у таких видах діяльності дитини, як образотворча діяльність, гра, спілкування, слухання та читання художніх творів і т.д. Різноманітна діяльність дитини є засобом залучення дитини до соціальної дійсності. Дорослий під час взаємодії із дитиною у різних видах діяльності може 
моделювати соціальні ситуації, що викликають емпатичні переживання дитини з метою корекції поведінки дитини у таких ситуаціях за допомогою рефлексії. Тому наступний етап повинен включати вправи, які спрямовані на розвиток поведінкової емпатії: читання літературних творів, у яких простежується співчуття, допомога одного літературного героя іншому; перегляд мультфільмів, фільмів, лялькових вистав і т.ін., основним змістом яких $є$ діяльнісна емпатія героїв; переказування дітьми ситуацій із особистого досвіду, що схожі із сюжетами прочитаних художніх творів, переглянутих кінофільмів, вистав і т.д.; бесіди про способи прояву поведінкової емпатії (порада, допомога, розуміння емоційного стану іншої людини і т.ін.).

Ще одним напрямком у розвитку емпатійності дітей молодшого шкільного віку може стати створення ситуацій «співрадості». Це може бути активна участь дітей у різноманітних святкових заходах у школі, організація спільних екскурсій, подорожей, відпочинку на природі, тематичних чаювань, днів народження, святкування традиційних національних свят i т.д. Ще одним дієвим, на наш погляд, методом психолого-педагогічного супроводу розвитку емпатії у молодшому шкільному віці є тематичні уроки. Їх метою має стати формування у дітей молодшого шкільного віку глибшого уявлення про гуманні та моральні якості особистості. Але варто зауважити, що усі діти різні. Вони по-різному сприймають інформацію, по-різному іiі інтерпретують та по-різному проявляють певні здібності. Це, звісно ж, стосується і емпатії. Тому процес розвитку емпатії у дітей молодшого шкільного віку є важким завданням і для дитини, і для педагога чи психолога. Цей процес варто побудувати так, щоб діти не відчували це як повинність, як обов'язкові уроки, заняття чи вправи. Тільки за таких умов робота буде ефективною.

Висновки і перспективи подальших розвідок. Таким чином, розвиток емпатії у дітей молодшого шкільного віку - це процес формування мимовільних моральних мотивів, мотивації діяльності на користь іншої людини. За допомогою емпатії дитина долучається до світу переживань інших людей, у неї формується уявлення про цінність іншої людини, розвивається і закріплюється потреба в емоційному благополуччі інших людей. У міру психічного розвитку дитини і структурування iї особистості емпатія стає джерелом сприятливого морального розвитку.

Узагальнюючи результати наукових досліджень та власних емпіричних даних ми можемо стверджувати, що у молодшому шкільному віці розвиток емпатії пов’заний 3 власним емоційним досвідом та зовнішнім контролем. В основі розуміння емоцій інших людей лежить рефлексія власних емоцій. Тому розвиток емпатії здійснюється через емоційне самоусвідомлення молодших школярів; молодший шкільний вік є сензитивним періодом для розвитку емоційного інтелекту; емпатія є основним психологічним механізмом розвитку міжособистісного емоційного інтелекту, який забезпечує успішність спілкування і соціальної взаємодії. Потребують подальшої розробки психолого-педагогічні технології розвитку емоційного інтелекту молодших школярів у процесі навчальної діяльності.

\section{СПИСОК ПОСИЛАНЬ}

Гаврилова, Т. П. (2009). Эмпатия и ее особенности у детей младмего и среднего школьного возраста. Москва: Наука.

Державний стандарт початкової освіти: Постанова Кабінету Міністрів України. № 668. (2019).

Дефуа, Н. (2014). Влияние медитативного тренинга на уровень и каналь эмпатии. Москва: LAP LAMBERT Academic Publishing.

Павелків, Р. В., \& Корчакова, Н. В. (2013). Просоціальний розвиток особистості: Монографія. Рівне: О. Зень.

Павелків, Р. В. (2001). Вікова психологія. Київ: Кондор.

Пономарева, М. А. (2006). Эмпатия: теория, диагностика, развитие: Монография. Минск: Бестпринт.

Степанов, О. М. (Авт.-упоряд.). (2006). Психологічна енциклопедія. Київ: Академвидав.

Сухомлинский, В. А. (1983). Мудрая власть коллектива. Москва: Прогресс.

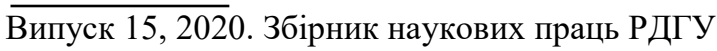




\title{
REFERENCES
}

Gavrilova, T. P. ( 2009). Empatiya $i$ eye osobennosti u detey mladshego $i$ srednego shkolnogo vozrasta [Empathy and its features in children of primary and secondary school age]. Moskva: Nauka. [in Russian].

Derzhavnyi standart pochatkovoi osvity. Postanova Kabinetu Ministriv Ukrainy [State standard of primary education: Resolution of the Cabinet of Ministers of Ukraine]. № 668. (2019). [in Ukrainian].

Defua, N. (2014). Vliyaniye meditativnogo treninga na uroven $i$ kanaly empatii [Impact of meditation training on the level and channels of empathy]. Moskva: LAP LAMBERT Academic Publishing. [in Russian].

Pavelkiv, R. V., \& Korchakova, N. V. (2013). Prosotsialnyi rozvytok osobystosti: Monohrafiia [Prosocial personality development: Monograph]. Rivne: O. Zen. [in Ukrainian].

Pavelkiv, R. (2001). Vikova psykholohiia [Age psychology]. Kyiv: Kondor. [in Ukrainian].

Ponomareva, M. A. (2006). Empatiya: teoriya. diagnostika. razvitiye: Monografiya [Empathy: theory, diagnostics, development: Monograph]. Minsk: Bestprint. [in Russian].

Stepanov, O. M. (Avt.-uporiad.). (2006). Psykholohichna entsyklopediia [Psychological encyclopedia]. Kyiv: Akademvydav. [in Ukrainian].

Sukhomlinskiy, V. A. (1983). Mudraya vlast kollektiva [Wise collective power]. Moskva: Progress. [in Russian].

\section{DEVELOPMENT OF EMPATHY IN PRIMARY SCHOOL-AGE CHILDREN IN THE CONTEXT OF THE EDUCATIONAL PROCESS}

\author{
Kulakov Ruslan \\ Candidate of Psychological Sciences, Associate Professor \\ Developmental and Educational Psychology Department \\ Rivne State University of the Humanities \\ http://orcid.org/0000-0003-0033-8784. \\ DOI https://doi.org/10.35619/praprv.v1i15.189
}

\begin{abstract}
The article is devoted to the current problem of modern psychological and pedagogical science - the development of empathy in children of primary school age as a basis for the development of emotional and sensory sphere, the ability to understand and control their feelings and experiences, and the ability and desire to understand emotions, feelings, the mood of another person. The publication substantiates the scientific and practical significance of the problem of empathy development in children of primary school age. The article considers the approaches to the definition of "empathy" in psychological science, gives certain points of view of scientists on nature and ontogenetic features of this socio-psychological phenomenon. The main types and forms of empathy are identified, its main functions are clarified. The article analyses the main levels of empathy. The main patterns of development of empathy among younger pupils in the context of the educational activities at school are examined. The role of teachers in the successful development of empathy of primary school-age children is determined. The publication analyzes the main stages, methods, forms and directions of psychological and pedagogical support for the development of empathy in primary school children. It is concluded that the development of empathy in children of primary school age is a relevant and popular problem in modern education.

Key words: empathy, empathic abilities, emotional sphere, primary school age, younger pupils, educational activities, educational process.
\end{abstract}

Стаття надійшла до редакиії 12.08.2020 p. 